\title{
Job Satisfaction and Employee Commitment of Public Hospitals in Rivers State, Nigeria
}

\section{Oparanma FU*}

Department of Nursing, Rivers State University, Nigeria

*Corresponding author: Florence U Oparanma, Department of Nursing, Rivers State University, Nigeria, Email: okachi@yahoo.com

\section{Research Article}

Volume 3 Issue 5

Received Date: August 06, 2019

Published Date: September 10, 2019

DOI: $10.23880 /$ nhij-16000199

\section{Abstract}

This study was set out to examine the association between job satisfaction and employees' commitment of Public Hospitals in Rivers State, Nigeria. Good reward system, timely promotion and good working condition were used as the empirical referent of job satisfaction while affective, normative and continuance commitments were used as measures of the commitment. Hypotheses were developed in order to determine the degree of positive linearity between job satisfaction and employee's commitment. Cross-sectional survey research design was adopted for the study. A total of one hundred and ten (110) respondents were drawn from a population of one hundred and fifty (150) based on sample size determination. Only ninety six (96) copies of the retrieved copies were used for the study. An inferential statistical tool of Pearson Product Moment Coefficient of Correlation was used. The result of the findings revealed that good reward system, timely promotion and good working conditions significantly influenced affective, nonnative and continuance commitment respectively. Based on empirical findings, the researcher then concluded that job satisfaction enhances employees' commitment of Public Hospitals in Rivers State, Nigeria. The researcher then recommends that Managers of Public Hospitals in Rivers State should pick interest in job satisfaction practices in order to advance employees' commitment. Management of public hospitals should focus on good reward system because it boosts employees' normative commitment.

Keywords: Job Satisfaction; Employee Commitment; Good Reward System

\section{Introduction}

Employee commitment is highly valuable. Studies have highlighted that commitment has a great impact on the successful performance of the organization. A committed employee has a stronger desire to belong to the organization and is willing to display greater organizational citizenship behavior, that is, a willingness to go over and beyond their required jobs duties. And if human resources are said to be an organizations greatest assets, then committed human resources should be regarded as an organizations competitive advantage. Committed employees who are highly motivated to contribute their time and energy to the pursuit of organizational goals are increasingly acknowledged to be the primary asset available to the organization [1]. They provide the intellectual capital, which for many organizations has become their most critical asset. With committed employees, there would be low absenteeism, 


\section{Nursing \& Healthcare International Journal}

productivity would be high, and employees are unlikely to leave their jobs.

Commitment is a belief, which reflects "the potency of an employee's bonding to an organization". The concept of employees' commitment has been examined and established to be a consequence of HRM practices in many studies [2,3].

It is therefore important for organizations to know the aspects that play important roles or have big impact in boosting the commitment of their employees. The opinion that job satisfaction matters in determining employee's commitment can be traced to the behavioral scientist such as the Hawthorne plant experiment by Elton, et al. on the influence of social attitude and relationship of work group on performance and the motivation theories that can affect human actions. Providing an enabling work environment for employee satisfaction is a component of corporate policies of the organization but domiciled as the function of human resource management. This is because human resource is the most vital assets for the organizational development [4]. Conceptually, job satisfaction refers to positive emotional state resulting from the pleasure a worker derives from the job, and as the effective and cognitive attitudes held by an employee about various aspect of their work [5].

\section{Literature Review}

\section{The Dimensions and Concept of Job Satisfaction}

The concept of job satisfaction has been defined in many ways. However, the most-used definition of job satisfaction in organizational research is that of Locke [6], who described job satisfaction as a pleasurable or positive emotional state resulting from the appraisal of one's job or job experiences. Building on this conceptualization, Judge, et al. [7] noted that job satisfaction includes multidimensional psychological responses to one's job, and that such responses have cognitive (evaluative), affective (or emotional), and behavioral components. This tripartite conceptualization of job satisfaction fits well with typical conceptualizations of social attitudes [8]. Job satisfaction is so important in that its absence often leads to Lethargy and reduced employee commitment.

\section{Good Reward System as a Dimension of Job Satisfaction}

The first aspect that comes to mind when we think about causes for job satisfaction is the reward a person gets while doing his job. Rewards can take a monetary form (money) or be a more intangible reward, like the feeling a person might get when doing a job that helps others (a nurse, for example). We can even think of a reward as the prestige you get for actually doing a job (as with a judge). Reward system is an important tool that management can use to channel job satisfaction in employees. Rewards are in the eyes of the beholder and are different for each person, who is why motivating a person with rewards means you must apply the correct reward to the person that is receiving it, else the recipient will not fill satisfied with the job. For example, rewarding a nurse for a job well done monetarily might not be the best call beyond paying her salary, but a reward like a gift from her patient might be more appreciated.

\section{Timely Promotion as a Dimension of Job Satisfaction}

Promotion is said to happen when an employee makes a shift in the upward direction in organizational hierarchy and moves to a place of greater responsibility [9]. Promotion can make a significant increase in the salary of an employee as well as in the span of authority and control. It will help the competitors to identify the most productive employees in the business world at the same time the employees are being recognized by their own organization. The employees themselves feel like an effective contributor and thus will be more satisfied with their job.

\section{Good Working Condition as a Dimension of Job Satisfaction}

Any organization that wishes to succeed in achieving its aims and objectives has to maintain a good working condition so as to achieve its goal. This is so because of the intrinsic and extrinsic factors. The intrinsic factor is the incentives attached to one's job that influences the employee within the job, and this includes achievement, recognition, the work itself, responsibility, promotion and possibility for personal growth; while extrinsic are the environmental condition attached to one's work element that contribute or motivate the employee e.g. interpersonal relationship with colleagues and subordinates.

Management itself realizes that there are certain fundamental needs that must be satisfied if the employee is to function at its best. Workers look for organization, firms, companies and institutions that offer job that provides good working conditions that gives a sense of accomplishment and satisfaction. It is an indisputable fact that employees are the backbone of any organization, and as such the working condition should be conducive to bring out the best in them. 


\section{Nursing \& Healthcare International Journal}

\section{Measures and Concept of Employee Commitment}

An organization with good employer-employee relationship will sure achieve their objectives without any loss out of their business. Employee commitment plays a vital role in the development of each and every organization all over the world. Employee commitment refers to the psychological attachment of employees to their workplaces. Commitment to organization is positively related to such desirable outcomes as job satisfaction and negatively related to such outcomes as absenteeism and turnover. Employee commitment is the loyalty and support of workforce towards the goals of an organization. Armstrong [10], post that commitment denotes an individual's strength of identification and involvement in an organization, and it plays an important part in Human Resources Management (HRM) philosophy. Employee commitment is the extent to which employees identify with the organization's work ethic, co-operate with its goals and objectives and contribute to corporate performance.

\section{Affective Commitment as a Measure of Employee Commitment}

Affective Commitment is the employees' positive emotion to the organization. An employee, who is committed affectively, identifies firmly with the objectives of the organization and tends to stay with the organization $[11,12]$. Affective commitment refers to the employees' emotional attachment to, identification with the organization and participation in the organization based on positive feelings or emotions towards the organization. The antecedents for affective commitment comprise of perceived job features (task autonomy, task significance, task identity, skill variety and managerial response), administrative reliability (the degree to which an individual trust the organization that they can take care of their welfares), and supposed involved management (the degree to which employees feel they have a say in decision making in the workplace and other issues that concerns them).

\section{Normative as a Measure of Employee Commitment}

Meyer, et al. [13], asserts that normative commitment is the employees' commitment to the firm due to their feelings of responsibility or obligation. Normative commitment could be derived from several sources. For instance, an organization may have invested resources in training the employees who then feel an ethical responsibility to expend effort on their work and remain with the organization. They maintained that these components are not mutually exclusive. Employees could at the same time be committed to an organization in an affective, continuance, and normative ways at varying levels of intensity. Employees could at any point in time have a commitment profile that reflects high or low levels of all components [14].

\section{Continuance Commitment as a Measure of Employee Commitment}

Continuance Commitment refers to employees' commitment to the firm due to their perceived great cost of losing affiliation with the organization. It comprises of loss of monetary costs such as pension accumulations and social costs (friendship ties with co-workers). Possible antecedents of continuance commitment comprises of age, tenure, career fulfillment and intent to leave. Age and tenure can act as the predictors of continuance commitment, mainly, because of their roles as substitute methods of investment in the firm [13].

\section{Relationship between Job Satisfaction and Employee Commitment}

In the labor market there is demand of highly skilled, trained and qualified employees. The output and productivity of an organization is measured in terms of the Performance of its workforce [15]. It was found that better performance of the workforce is as a result of the level of job satisfaction [16].

\section{The Impact of Reward System on Employee Commitment}

Job satisfaction is an outcome of different factors like reward, the work itself, supervision, relationship with coworkers and opportunities for promotions [17]. Out of these factors, reward is a very important factor. Frye found that there is positive relationship between equity based reward and commitment. It was further concluded that reward plays vital role in human capital intensive firms to attract and retain expert workforce. Furthermore, the reward system has significant impact on employee commitment. It was also found that flexible reward has no effect on the level of commitment [18]. The study regarding reward of public sector managers was conducted and it was concluded that the reward is the major determinants of employee commitment [19]. The investigation about the relationship between employee commitment and reward was conducted, and it was discovered that employee commitment if affected by reward [20]. 


\section{The Impact of Promotion on Employee Commitment}

Promotion is an essential practice of human resource management which can have a considerable impact on employee commitment. Akintoye [21] found the influence of different determinants of employee commitment. Several studies focus on the demographic factors, while others link the employee commitment with reference to promotion. The other factors such as fair job autonomy, leadership behavior, and social relations are also the dominant in determining the level of employee commitment [22]. Nguyen, et al. [20] concluded that employee commitment is the result of promotion opportunity in the organization.

\section{The Impact of Working Condition on Employee Commitment}

Working condition is an important determinant of employee commitment [23]. The work environment in the new research was found to be a better determinant or employee commitment by the scholars [24-27]. Moreover, variation exists in terms of pay packages, incentives, recognition and fringe benefits for the employees [28]. It was found that employee commitment is adversely affected by factors such as lack of promotion, working conditions, low job security and low level of autonomy.

\section{Methodology}

In this study, correlational survey research design was adopted in a cross-sectional manner. The information obtained from the ministry of health and hospital management board shows that there are 50 hospitals and health centers in Rivers State. For convenience, in terms of data collection, the study focused on five (5) randomly selected public hospitals as the population of this study which was randomly selected from different parts of Rivers State. Thirty (30) medical employees were randomly selected from each hospital; hence the total population was one hundred and fifty (150) medical/health employees as shown in the population frame below Tables 1 \& 2 .

\begin{tabular}{|c|c|c|}
\hline S/N & Names of the Hospitals & Population (N) Sample size \\
\hline 1 & Rivers State University Teaching Hospital. & 3022 \\
\hline 2 & University of Port Harcourt Teaching Hospital. & 3022 \\
\hline 3 & Rumuigbo Health Centre & 3022 \\
\hline 4 & Elele General Hospital & 3022 \\
\hline 5 & Isiokpo General Hospital & 3022 \\
\hline & Total & $\mathbf{1 5 0 ~ 1 1 0}$ \\
\hline
\end{tabular}

Table 1: Population and Sample size determination of the Employees.

Source: (Management Records of Operating Selected Public Hospitals in Rivers State)

Data Presentation, Analysis and Discussion of Findings

\begin{tabular}{|c|c|c|c|}
\hline & No of Cases & Percent & Valid Percent \\
\hline Copies Administered & 110 & 100 & 100 \\
\hline Copies Retrieved & 104 & 95 & 95 \\
\hline Uncompleted Copies & 6 & 5.5 & 5.5 \\
\hline Completed and unusable Copies & 2 & 0.02 & 0.02 \\
\hline Completed and usable Copies & 96 & 100 & 100 \\
\hline
\end{tabular}

Table 2: Response Rate of Copies of Questionnaire Distributed and Retrieved.

Source: SPSS Field Work Data Output, 2018

\section{Interpretation}

Table 2 shows the result for the field work-outcomes which revealed that out of one hundred and ten (110) copies of the questionnaire distributed representing 100 percent. One hundred and four (104) were successfully retrieved, indicating $95 \%$ of the total copies of questionnaire distributed thus indicating a high response rate. Six (6) copies of the questionnaire were uncompleted or not retrieved representing $5.5 \%$ of the total copies of questionnaire administered which is insignificant compared to the copies retrieved and did not adversely affect the result of the study. After editing and coding, ninety (96) copies of questionnaire out of one 


\section{Nursing \& Healthcare International Journal}

hundred and four (104) copies of the questionnaire retrieved were found useable for inclusion in the analysis.

\section{Data Analysis Technique}

The Statistical Package for Social Science (SPSS) 1.0 was used for the analysis. The study adopted descriptive analytical tools and inferential statistical tools in analyzing the data gotten from the field. The analysis was carried out at primary, secondary and tertiary levels respectively. The primary stage of the analysis had to do with the analysis of demographic properties of the respondents. The primary level analysis was correctly used for the analysis of demographic properties of the respondents was frequency distribution tables supported with chats due to the nominal scale type of data set generated, while at the secondary level, the descriptive analytical tool that was rightly used for univariate analysis of the data was descriptive statistics which assured normality in the spread and measures of central tendencies (mean scores) and dispersion (standard deviation) and helped in providing answers to items poised on each study variable.

\section{Summary}

The study has been able to institute empirically the relationship between job satisfaction and employees' commitment of five (5) selected Public Hospitals in Rivers State, Nigeria giving definitions, concepts and the factors in them. Research questions were postulated and research hypothesis formulated for the study using the dimension of job satisfaction which were good reward system, timely promotion and good working condition and the measures of employees' commitment which consist of affective, normative and continuance commitment respectively.

\section{Conclusion}

In conclusion, good working condition had a significant influence on normative commitment and job satisfaction leads to employees' commitment. Therefore, management of the five (5) selected Public Hospitals in Rivers State, Nigeria should take into consideration the impact of good working condition on employees' normative commitment and in order to guarantee quality job satisfaction, management of Public Hospitals should implement policies promoting worthy job satisfaction practices in the various Health centers and Public Hospitals in Rivers State, Nigeria.

\section{Recommendations}

From the findings of the study, the following were recommended:

> Management of Public Hospitals in Rivers State, Nigeria should align the policies of their hospitals to suit and promote job satisfaction.

$>$ Management of Public Hospitals in Rivers State, Nigeria should implement hospital policies that will facilitate good reward system because it is the key to employees' normative commitment.

$>$ Management of Public Hospitals in Rivers State, Nigeria should pick interest in job satisfaction practices in order to advance employees' commitment (EC).

$>$ Public Hospitals in Rivers State, Nigeria should stimulate good reward system of their employees in order to ensure continuance commitment.

$>$ Public Hospitals in Rivers State, Nigeria should stimulate timely promotion of their employees in order to ensure employees' affective commitment.

$>$ Public Hospitals in Rivers State, Nigeria should adopt good working condition of their employees as a dimension of job satisfaction in trying to ensure normative and continuance commitment.

\section{References}

1. Hunjra AI, Chani MI, Aslam S, Azam M, Rehman KU (2010) Factors effecting job satisfaction of employees in Pakistani banking sector. African Journal of Business Management 4(10): 2157-2163.

2. DeCotiis TA, Summers TP (1987) A path analysis of a model of the antecedents and consequences of organizational commitment. Human Relations 40(7): 445-470.

3. Mathieu JE, Zajac DM (1990) A review and metaanalysis of the antecedents, correlates, and consequences of organizational commitment. Psychological bulletin 108 (2): 171-194.

4. Liu DM, Alameda CK (2011) Social determinants of health for Native Hawaiian children and adolescents. Hawaii Med J 70 (11): 2-9.

5. Mercer CD (1997) Students with learning disabilities. USA, Prentice Hall.

6. Locke EA (1976) The nature and causes of job satisfaction. Handbook of industrial and organizational psychology, Chicago: Rand McNally 1: 1297-1343. 


\section{Nursing \& Healthcare International Journal}

7. Judge TA, Hulin CL (1993) Job satisfaction as a reflection of disposition: A multiple source causal analysis. Organizational Behaviour and Human Decision Processes 56(3): 388-421.

8. Eagley AH, Chaiken S (1993) The psychology of attitudes. Harcourt Brace Jovanovich College Publishers.

9. Dessler G (2009) A framework for human resource management. India: Pearson Education.

10. Armstrong M, Taylor S (2014) Armstrong's handbook of human resources management practice. NY: Kogan Page Publishers.

11. Kanter RM (1984) The change masters: Innovation and entrepreneurship in the American corporation, New York: Simon and Schuster.

12. Mowday RT, Porter LW, Steers R (1982) Organizational linkage: The psychology of commitment, absenteeism and turnover. New York, NY: Academic Press. NHS Information centre (2008). Statistics/Data Collections-Prescriptions 10(3): 2018.

13. Allen NJ, Meyer JP (1993) Organizational commitment: evidence of career stage effects? Journal of Business Research 26(1): 49-61.

14. Meyer JP, Stanley DJ, Herscovitch L, Topolnytsky L (2002) Affective, continuance, and normative commitment to the organization: a meta-analysis of antecedents, correlates, and consequences. Journal of Vocational Behavior 61(1): 20-52.

15. Currall SC, Towler AJ, Judge TA, Kohn L (2005) Pay satisfaction and organizational outcomes. Personnel Psychology, 58(3): 613-640.

16. Souza Poza A, Hennebergers F (2000) Work Attitudes, Work Conditions and Hours Constraints: An Explorative, Cross-national Analysis. Labour 14(3): 351-372.

17. Okpara JO (2002) The influence of ethical climate types on job satisfaction of IT managers: implications for management practice and development in a developing economy. In Academy of Business and Administrative services Seventh International Conference, pp: 6-8.
18. Igalens J, Roussel P (1999) A study of the relationships between compensation package, work motivation and job satisfaction. Journal of Organizational Behaviour 20(7): 1003-1025.

19. Sokoya SK (2000). Personal predictor of job satisfaction for the public sector manager. European Management Journal 21: 11-23.

20. Nguyen AN, Taylor J, Bradley S (2003) Job autonomy and job satisfaction: new evidence. Lancaster University Management School. Working paper: 50.

21. Akintoye IR, Owojori AA, Adidu FA (2011) The challenge of risk management in Nigerian banks in the post consolidation era. Journal of Accounting and Taxation 3(2): 23-31.

22. Dawson S (1992) Analyzing organizations, UK Springer Publishers.

23. Yang LQ Che H, Spector PE (2008) Job stress and well-being. An examination from the view of personenvironment fit. Journal of Occupational and organizational Psychology 81(3): 567-587.

24. Reiner MD, Zhao J (1999) The determinants of job satisfaction among United States Air Force Security Police: A test of rival theoretical predictive models. Review of Public Personnel administration 19(3): 518.

25. Carlan PE (2007) The search for job satisfaction: a survey of Alabama policing. American Journal of Criminal Justice 32(1-2): 74-86.

26. Ellickson MC, Logsdon K (2001) Determinants of job satisfaction of Municipal Government employees. State and Local government Review 33(3): 173-184.

27. Forsyth CJ, Copes JH (1994) Determinants of job satisfaction among police officers. International Review of Modern Sociology 12: 109-116.

28. Lavy V (2009) Performance pay and teachers' effort, productivity, and grading ethics. The American Economic Rev iew 99(5): 1979-2011. 